\title{
Detection of Latent Peronospora effusa Infections in Spinach
}

Chaitra S. Subbarao, University of Southern California, Los Angeles 90007; Amy Anchieta, and Lorena Ochoa, United States Department of Agriculture-Agricultural Research Service (USDA-ARS), Salinas, CA 93905; Nikhilesh Dhar, Sridhara G. Kunjeti, and Krishna V. Subbarao, Department of Plant Pathology, University of California, Davis, c/o U.S. Agricultural Research Station, Salinas 93905; and Steven J. Klosterman, ${ }^{\dagger}$ USDA-ARS, Salinas

\begin{abstract}
Downy mildew disease of spinach, caused by Peronospora effusa, is managed in conventional fields by a combination of host resistance and scheduled fungicide applications. Fungicides are currently applied to prevent downy mildew epidemics regardless of the infection status of spinach crops. A more streamlined approach would be to develop methods to target either latent infections for fungicide application in conventional production systems or to hasten harvest in organic production. In this study, conventional polymerase chain reaction (PCR) was applied to detect $P$. effusa DNA in symptomless spinach leaves in three spatially and temporally separated field plots, each containing four $2-\mathrm{m}$ beds, $35 \mathrm{~m}$ in length. Spinach leaves were sampled weekly at 3-m intervals at 48 locations throughout each plot. Initial samples were asymptomatic and yet

PCR enabled detection of $P$. effus $a$ DNA extracted from sampled spinach leaves. Detection of latent downy mildew infection in spinach leaves was confirmed by PCR as early as 7 days prior to symptom development. The limit of pathogen DNA detection in spinach leaves was calculated at 10 pg using the conventional PCR approach. Quantitative PCR with TaqMan methodology revealed the presence of inhibitors from spinach leaf DNA extracts and affected amplification efficiencies, but not when diluted, enabling detection of $P$. effusa DNA at a concentration of $<0.1 \mathrm{pg}$. In conclusion, detection of latent infections may enable management decisions for earlier-than-normal harvest of infected, symptomless organic crops, and for timing fungicide applications on symptomless plants in conventional production.
\end{abstract}

Spinach (Spinacia oleracea L.) is a major crop in coastal California, accounting for nearly $65 \%$ of the U.S. production, with an annual production value of approximately $\$ 240$ million (NASS 2015). About $40 \%$ of this production occurs in the Salinas Valley, a region that also produces many other leafy greens (NASS 2015). Nearly all of the spinach grown from March through November in this region is for fresh market, with only a small portion dedicated to processing or "freezer" spinach during the winter months (Koike et al. 2011). The popularity of precleaned, ready-to-eat bagged salad mixes has led to increased production of baby leaf spinach since the mid-1990s (Atallah et al. 2010). Seeding rates for baby leaf spinach production typically range from 8.5 to 10 million seedlings/ha (Koike et al. 2011; Short et al. 2015), and it is the high planting density coupled with overhead irrigation that provide ideal conditions for the development of downy mildew (Klosterman 2016).

Downy mildews are obligate plant pathogens that cause widespread losses on many plant species (Thines and Choi 2016). Downy

${ }^{\dagger}$ Corresponding author: S. J. Klosterman;

E-mail: Steve.Klosterman@ARS.USDA.GOV

Funding: We acknowledge the funding for this project from the California Leafy Greens Research Program.

This work was initiated as a Salinas High School science fair project for senior author C. Subbarao, whose project was selected for statewide competition in California in 2015 as well as for the Intel Science and Engineering Fair held in Pittsburgh the same year. The article was also presented as a poster at the American Phytopathological Society meeting in Pasadena, CA in 2015.

Mention of trade names or commercial products in this publication is solely for the purpose of providing specific information and does not imply recommendation or endorsement by the United States Department of Agriculture (USDA). USDA is an equal opportunity provider and employer.

*The $\boldsymbol{e}$-Xtra logo stands for "electronic extra" and indicates that one supplementary figure and one supplementary table are published online.

Accepted for publication 5 April 2018.

This article is in the public domain and not copyrightable. It may be freely reprinted with customary crediting of the source. The American Phytopathological Society, 2018. mildew caused by Peronospora effusa (Grev.) Rabenh. (formerly $P$. farinosa f. sp. spinaciae) (Choi et al. 2007) is the most serious disease threat to spinach in California and elsewhere (Correll et al. 2011; Koike et al. 2011). Symptoms include chlorotic spots on the adaxial surface of spinach leaves accompanied by gray sporulation on the abaxial surface that renders the leaves unmarketable. With the increasing popularity of precleaned, bagged salad mixes (Atallah et al. 2010; Wu and Subbarao 2014) in which spinach is a major component, occasionally downy mildew-infected spinach leaves make their way into the bags, despite the careful screening of the harvested material prior to bagging. Spinach leaves with latent downy mildew infections may also enter the salad bags undetected. The disease can progress within the high humidity environment of the sealed salad bags, in which leaves can become symptomatic and thereby reduce the shelf life of spinach and other salad products mixed with spinach.

Downy mildew growth on the abaxial surface of infected leaves contains numerous sporangiophores that release sporangia into the air, which often travel short distances to nearby spinach crops; however, a portion of sporangia travel long distances (Choudhury et al. 2016, 2017) and are capable of causing infection kilometers away from the original infection site. Klosterman et al. (2014) developed a TaqMan real-time quantitative polymerase chain reaction (qPCR) assay based on $18 \mathrm{~S}$ ribosomal DNA (rDNA) sequences that differentiates $P$. effusa from the closely related $P$. schachtii (Choi et al. 2015). The qPCR assay was applied to quantify airborne inoculum, employing impaction spore trap samplers around spinach fields. Modeling the inoculum data obtained from impaction spore trap samplers from across the Salinas Valley, Choudhury et al. (2016) determined the ubiquitous presence of the pathogen as well as periods of high disease risk for spinach crops, and established a correlation between the numbers of airborne $P$. effusa sporangia detected and the disease incidence of diseased plants. Although the airborne spores serve as the primary inoculum in most circumstances, $P$. effusa also produces oospores (Eriksson 1919; Kunjeti et al. 2016b) that survive long term and transmit the disease from infested seed (Inaba et al. 1983).

Spinach downy mildew is currently managed with a combination of resistant cultivars and regular fungicide applications (Correll et al. 2011; Klosterman 2016). Fungicides are routinely applied around irrigation schedules whether or not the pathogen is detected. The expanding organic spinach production, which cannot use synthetic chemical fungicides (Feng et al. 2014), likely augments the 
inoculum production that increases during the major spinach growing season throughout the Salinas Valley (Choudhury et al. 2016). Thus, a more efficient method to prevent the disease from developing into an epidemic in both conventional and organic production systems would optimize fungicide usage in the former and provide information to schedule early harvests before sporulation occurs in the latter, contributing to reductions in yield losses and overall inoculum production in the Salinas Valley.

Early and accurate detection of these symptoms has relied on several approaches, including remote sensing (Nutter et al. 2010), thermography, fluorescence measurements, hyperspectral imaging and nonimaging sensors (Mahlein et al. 2012), commercially available immunoprinting kits, and lateral flow devices (De Boer and Lopez 2012). Nearly all of these methods detect and identify diseases on plants exhibiting symptoms. Once sporulation is observed, disease management, even with the most effective fungicides, becomes difficult because new infections can occur from the ubiquitous airborne inoculum.

Prevention of epidemic development may be possible by timely fungicide applications (during the latent period) or early harvest in conventional and organic production systems, respectively. This would, in turn, optimize fungicide usage and reduce pathogen sporulation, leading to improved disease control and reduced fungicide resistance (Brent and Hollomon 2007). Chanda et al. (2014) followed a similar approach to identify latent infections caused by Cercospora kikuchii in soybean and, in this case, early application of fungicides reduced the overall fungal biomass in the mature, infected soybean plants. Some assays have been developed to detect pathogens in leaf tissues, for the purpose of making disease management decisions (Miles et al. 2015; Si Ammour et al. 2017) and to aid in the screening of plant genotypes for improved resistance (Knüfer et al. 2016).

The objectives of this study were to determine the feasibility of detection of latent infections caused by P. effusa on spinach and to validate the technique in spatially and temporally separated field plot experiments. This work represents a proof-of-concept that required initial studies in field plots to examine the disease progression in the universally susceptible cultivar Viroflay, thereby reducing the complexity of host gene-pathotype interactions to routinely obtain disease. Preliminary results have been previously published (Subbarao et al. 2015).

\section{Materials and Methods}

Spinach field plots. Three field plot experiments were conducted to detect $P$. effusa infection in spinach during the latent period. Spinach cultivar Viroflay, susceptible to all known $P$. effusa pathotypes (Correll et al. 2011), was obtained from Gourmet Seed International, LLC (Tatum, NM). The plantings were done at the United States Department of Agriculture-Agricultural Research Service station in Salinas, CA in November 2014 (plot 1), November 2015 (plot 2), and August 2016 (plot 3), and each plot was maintained for approximately 3 months to follow downy mildew disease development under natural conditions. The periods over which the crops were maintained were beyond typical commercial production schedules because plant development in the experimental plots was slower than in commercial fields.

Each of the field plots included four beds of $2 \mathrm{~m}$ in width and $36 \mathrm{~m}$ in length. Plots were seeded at high density, similar to commercial fields for baby leaf spinach (Koike et al. 2011), at a rate of 8.5 million seeds/ ha. The Viroflay seed used in the experimental plots were examined for the presence of oospores in advance, because oospores commonly occur on commercial spinach seed lots (Inaba et al. 1983; Kunjeti et al. 2016b). The Viroflay seed were negative for oospores of $P$. effusa, as determined by a seed wash approach with 1,000 seeds (Kunjeti et al. 2016b). The plots were irrigated with sprinklers and crop management practices followed were standard for the growing area.

Disease incidence. Disease incidence in plots 1 and 3 were calculated weekly, beginning 4 or 5 weeks after planting, as the percent downy mildew symptomatic leaves in a $0.3-\mathrm{m}^{2}$ area per sampling site, for a total of 48 sites/plot. Each sampling site was separated by $3 \mathrm{~m}$. Unlike field plots 1 and 3, detailed disease incidence data at the 48 sites in plot 2 were not collected. Rather, the overall field was examined for the presence of leaf symptoms by walking through the rows, twice per week. Similarly, field plots 1 and 3 were also examined at a rate of 5 days/week by walking the plots, to determine the timing of first symptom appearance, in addition to the detailed weekly disease incidence data on percentage of leaves infected. In all field plots, plant development was slower than during typical production periods and, hence, the symptoms in these plots occurred when a typical baby leaf spinach field is harvested, at approximately 4 weeks after planting (Koike et al. 2011).

Sample collection. Sampling of spinach leaves for pathogen detection before symptom development (during the latent period) began 4 weeks after planting, based on previous knowledge of symptom appearance under conditions of natural spinach infections in the fall and winter field plots (Choudhury et al. 2017). Each of the spinach leaf samples from two plants were collected at 3-m intervals in the middle of each bed for a total of 48 samples across all beds at each weekly sampling time points for 5 to 6 weeks. Because the samples from the field were labeled 1 to 48 so that their location could be identified, it was possible to study the spread of $P$. effusa via detection through the plot. To avoid cross-contamination of spores between samples, gloves were changed between each sample. All leaf samples were transported to the laboratory and $50 \mathrm{mg}$ of tissue was removed from the leaves of two different plants, for a total of $100 \mathrm{mg} / \mathrm{sample}$, which was placed in 1.5-ml tubes using tweezers. Tweezers were washed with ethanol and wiped with a paper towel between the handling of each of the samples. Samples were stored at $-80^{\circ} \mathrm{C}$ until the DNA extractions could be performed.

DNA extraction. DNA extractions were performed with the NucleoSpin96 Plant II DNA kit (Macherey-Nagel, Bethlehem, PA) using $100 \mathrm{mg}$ in total of the spinach leaf tissue. Leaf tissue $(50 \mathrm{mg})$ was obtained from the middle portion of each of two leaves from the two separate plants, collected as described above. The pooled 100-mg sample was ground in $500 \mu \mathrm{l}$ of extraction buffer PL1 (containing RNAse A) using 3-mm steel beads in a TissueLyser (Qiagen, Valencia, CA) for two cycles of $1 \mathrm{~min}, 30 \mathrm{~Hz}$, at room temperature. Samples were incubated at $70^{\circ} \mathrm{C}$ for $30 \mathrm{~min}$ before being centrifuged at full speed for $10 \mathrm{~min}$. The extraction protocol was followed according the manufacturer, although the elution step was performed with $100 \mu \mathrm{l}$ of elution buffer at $70^{\circ} \mathrm{C}$. As spinach plants in the field became symptomatic, the symptomatic portions of leaves were purposefully targeted for DNA extractions. For the purposes of testing PCR inhibition, the spinach leaf DNA concentrations were adjusted to 15 to $30 \mathrm{ng} / \mu \mathrm{l}$, with a $260 / 280$ ratio of 1.85 to 1.9 .

Conventional PCR and electrophoresis. For the PCR assay, $5 \mu \mathrm{l}$ of the eluate containing DNA template, extracted as described above, was used in the PCR with P. effusa-specific primers AS1 and PeR1 (Klosterman et al. 2014) on a PTC-200 thermal cycler (Bio-Rad, Hercules, CA). The PCR included $5 \mu \mathrm{l}$ of extracted DNA template, $200 \mathrm{nM} P$. effusa-specific primers (AS1 and PeR1), and 1× GoTaq DNA Polymerase mix (Promega Corp., Madison, WI) in a total volume of $25 \mu$ l. Reactions were performed on a PTC-200 thermocycler under the following cycling conditions: $94^{\circ} \mathrm{C}$ for $5 \mathrm{~min}$ and 35 cycles of $94^{\circ} \mathrm{C}$ for $30 \mathrm{~s}, 60^{\circ} \mathrm{C}$ for $30 \mathrm{~s}$, and $72^{\circ} \mathrm{C}$ for $30 \mathrm{~s}$. A final extension of $72^{\circ} \mathrm{C}$ was used for $5 \mathrm{~min}$. The amplified products were loaded on $2 \%$ agarose gels in $0.5 \times$ Tris-borate-EDTA buffer (components from Fisher Scientific, Waltham, MA). The gel was stained with GelRed (Biotium Inc., Fremont, CA) (Huang et al. 2010) according to the manufacturer's instructions. A 100-bp ladder (Promega Corp.) was used for estimation of the size of smaller DNA fragments following electrophoresis and gel staining. Positive-control DNA samples were derived from $P$. effusa-infected spinach leaves or DNA extractions from sporangia washed off of leaves, while negative controls were derived from a no-template water control. Previous testing revealed that PCR with DNA template from noninfected spinach tissue are negative when employing the primer pair AS1 and PeR1 (Klosterman et al. 2014) (data not shown). The specificity of primer pair AS1 and PeR1 for $P$. effusa DNA amplification in the background of spinach cultivar Viroflay DNA was previously established (Klosterman et al. 2014). 
Upper and lower bound confidence intervals for the percentage of samples that were positive for pathogen detection among the three field plot trials were calculated based on the Clopper-Pearson exact method (Madden et al. 2007).

TaqMan assays. TaqMan assays for $P$. effusa quantification were carried out as described previously (Klosterman et al. 2014) using $5 \mu \mathrm{l}$ of spinach leaf extract as template. Standard curves were prepared with purified $P$. effusa DNA dilutions of 10 to $0.0001 \mathrm{ng}$ that were spiked or not spiked with $5 \mu l$ of spinach leaf DNA obtained using the NucleoSpin Plant II DNA extraction kit (MachereyNagel), as described above. Curves were also prepared using $P$. effusa DNA template dilutions ranging from $2.5 \mathrm{ng}$ to $2.5 \mathrm{pg}$, with $5 \mu \mathrm{l}$ of spinach leaf DNA. Linear regression analyses were used to calculate the amplification efficiencies.

For correlation analyses of DNA concentration values with disease incidence over time for experimental plot 3 , the quantification cycle (Cq) values obtained from these assays were averaged by week and its relationship with the corresponding disease incidence was determined by regression analyses using a 10 to $0.0001 \mathrm{ng}$ DNA standard curve prepared with spinach leaf extract spiked with genomic DNA (Supplementary Table S1).

\section{Results}

No downy mildew symptoms or signs were observed until 5 or 6 weeks after planting in the three field plots (Fig. 1; Table 1), despite the detection of $P$. effus $a$ DNA extracted from spinach leaves by conventional PCR (Fig. 1; Table 1). Observations during subsequent weeks revealed increasing numbers of leaves with downy mildew symptoms, represented by the observed increases of disease incidence in field plot 1 and field plot 3 (Fig. 1).

The limits of $P$. effusa DNA detection in leaf tissues were examined by qPCR using TaqMan assays and conventional polymerase chain reactions (Fig. 2). Reproducible amplification at the 10-pg limit of detection is illustrated in Figure 2A, which shows the presence of qPCR inhibitors in all those reactions where the spinach leaf DNA was present, indicated by increases in $\mathrm{Cq}$ values in the presence of the leaf extract (Fig. 2A). Linear regression analyses revealed that the qPCR efficiencies for those reactions in the presence or absence of the leaf extract were 74.0 and $89 \%$, respectively (Fig. 2A). However, subsequent experiments revealed no inhibition of the TaqMan assay after dilution of the leaf extract from 150 to $10 \mathrm{ng}$ of DNA from spinach extract. Amplification in the presence of the leaf extract was observed with $0.1 \mathrm{pg}$ of $P$. effusa DNA for the TaqMan assay. Hence, the limit of detection for the TaqMan assay was $0.1 \mathrm{pg}$. Conventional PCR amplification of DNA using $P$. effusa-specific primer pair AS1 and PeR1 and $P$. effus $a$ DNA concentrations revealed that the limit of $P$. effusa DNA detection in the presence of spinach leaf DNA was 25 pg (Fig. 2B). Additional analyses revealed a conventional PCR limit of detection of $10 \mathrm{pg}$, though a twofold template dilution was not successful in increasing sensitivity (data not shown). The conventional PCR yielded no product in the leaf DNA control or in the notemplate negative control (Fig. 2B). The confidence intervals for PCR-based detection shown in Table 1 revealed an upper confidence limit at nearly $7.4 \%$, indicating a false-negative detection rate of nearly $7 \%$.

The qPCR analysis of the field samples revealed that, as disease incidence increased, the overall $\mathrm{Cq}$ values dropped, as represented by the results from experiment three (Fig. 3). The lower Cq values in each of the experiments at the later stages of the epidemic, when nearly all leaves were symptomatic, is consistent with the higher amount of pathogen DNA in those leaves. The $\mathrm{Cq}$ values ranged from $24.42 \pm 0.00$ to $37.16 \pm 0.00$ among the initially asymptomatic 48 leaf samples collected in week 4 and $16.45 \pm 0.56$ to $22.13 \pm 0.35$ among the 48 samples collected in week 9 (data not shown). The average detection concentrations in leaves at the first week of sampling for experiment three yielded an average $\mathrm{Cq}$ of 34.5. In the final week, the average concentration detected was $3 \mathrm{ng}$ of DNA, with an average $\mathrm{Cq}$ of $18.8 \pm 1.39$. Thus, all PCR products were also readily detectable at week 9 after planting, as shown on the agarose gels (Supplementary Fig. S1). In contrast, few DNA products were shown in the lanes after conventional PCR, although lane 16 from the week 4 gel showed the brightest intensity band, and this also corresponded to the $\mathrm{Cq}$ value of $24.42 \pm 0.00$ obtained from this same sample by qPCR analysis.

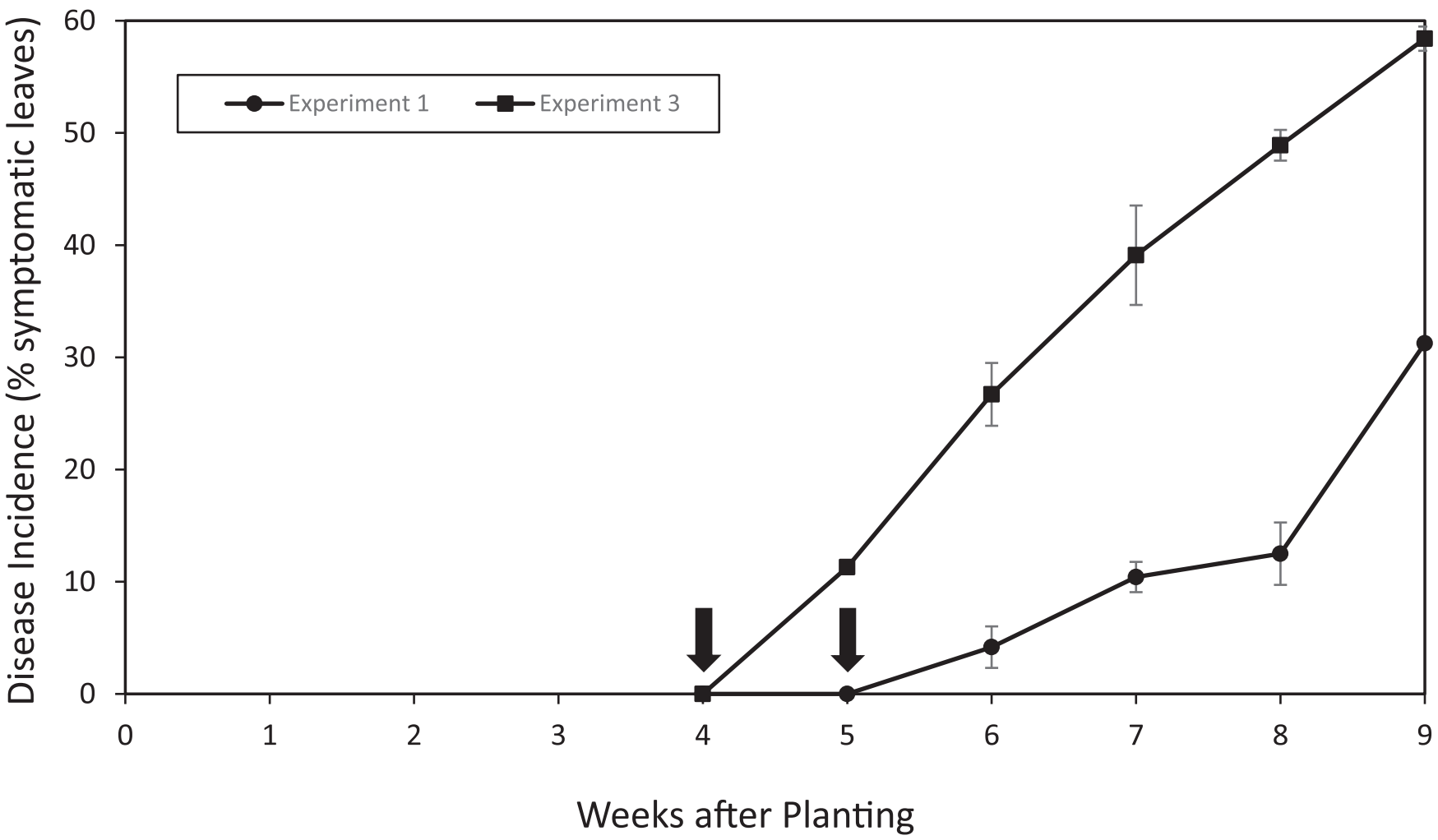

Fig. 1. Spinach downy mildew disease incidence and early detection of DNA from Peronospora effusa in leaves. Detection of $P$. effusa DNA during latent infection periods, 1 week prior to the appearance of symptoms, is indicated by the arrows. 
In two of the three field plot experiments, increased disease detection correlated with increased numbers of samples positive for pathogen DNA detection (Table 1). This is illustrated in Figure 3, where the relationship between mildew incidence and $P$. effusa DNA quantities is shown on a logarithmic scale, with an $R^{2}$ of 0.84 (Fig. 3). This change corresponded to $11.3 \%$ symptomatic leaves at week 5 after planting to an average of $58.4 \%$ symptomatic leaves by week 9. At 4 weeks after planting, however, no samples were symptomatic (Table 1; Fig. 1), and yet 15 of the leaf samples collected at this time point were positive for $P$. effusa DNA. In each of the experiments, a 67-bp product was present in each of the positive control lanes and those positive for $P$. effusa DNA but not in the negative control lanes, consistent with previous findings on the specificity of amplification of $P$. effusa DNA using primer pair AS1 and PeR1 from spinach leaf samples (Klosterman et al. 2014).

The distribution of the latent infections observed by pathogen DNA detection in leaves throughout the field plots was notably different in field plot 2 compared with field plots 1 and 3 . The 48 leaf samplings at 5 weeks after planting of field plot 2 revealed that only 16 of 48 samples were positive (Table 1), on only the two northernmost beds (distribution not shown). In contrast, by 6 weeks after planting in the same plot, 40 of 48 of samples were positive for $P$. effusa (Table 1) in a uniform distribution over the entire plot, suggestive of disease spread. In field plots 1 and 3, the distribution of downy mildew disease symptoms was more uniform over all four beds in each experiment over the course of the weekly observations.

\section{Discussion}

The application of a latent infection detection assay for $P$. effusa in leaves may be useful to guide management decisions on whether to harvest organic crops prior to symptom development, especially when coupled with knowledge of disease-conducive weather conditions. Because spinach leaves with latent downy mildew infections may enter salad bags undetected, this technology may help guide decisions that potentially prevent the entry of infected leaves into the bagged salad production stream. Secondarily, more judicious fungicide applications are projected to decrease the overall dispersal of spinach downy mildew inoculum in the Salinas Valley, in addition to slowing the development of fungicide resistance in the pathogen, because fungal and oomycete pathogens develop fungicide resistance in the field (Brent and Hollomon 2007).
Rather than relying on indirect spore-trap-based systems (Choudhury et al. 2016; Klosterman et al. 2014; Ojiambo et al. 2015), assessment of the $P$. effusa DNA in leaf samples can provide direct evidence of downy mildew-host association, allowing a grower to

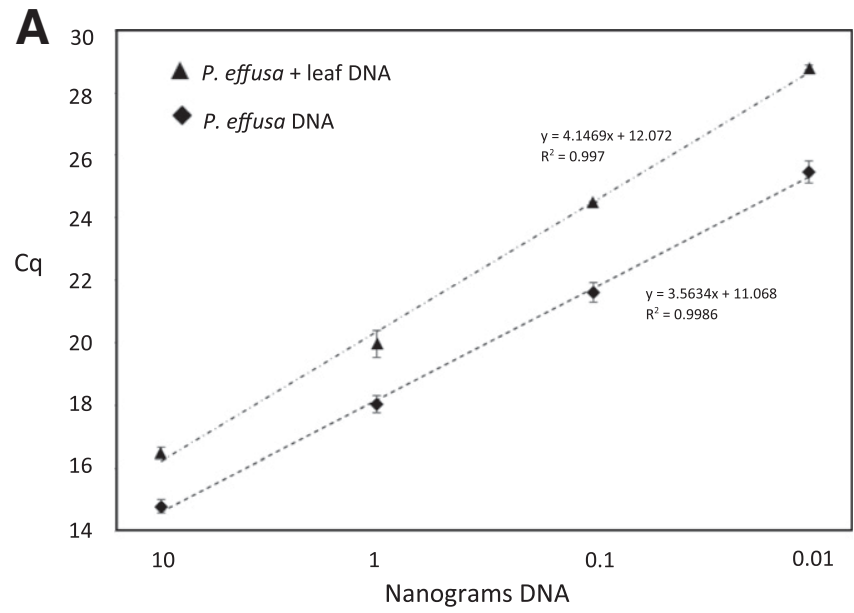

B

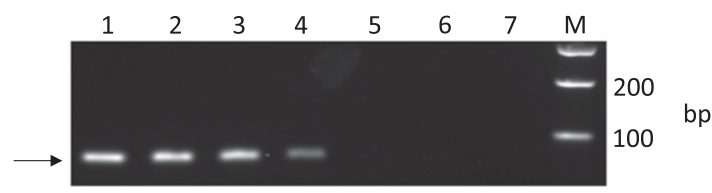

Fig. 2. Detection of DNA from Peronospora effusa using TaqMan assays and conventional polymerase chain reactions. A, TaqMan assays using $P$. effusa-specific primer pair AS1 and PeR1 and the Pef1 probe that targets the 18S ribosomal DNA sequence (Klosterman et al. 2014) in the presence or absence of spinach leaf DNA. Each of the curves was developed from three replicates. Error bars represent standard deviation. B, Conventional polymerase chain reaction (PCR) amplification of DNA using $P$. effusa-specific primer pair AS1 and PeR1 and $P$. effusa DNA concentrations of $25,2.5,0.25,0.025$, and $0.0025 \mathrm{ng}$ in lanes 1 to 5 , respectively, mixed with DNA extracted from leaves. The conventional PCR was also carried out with the leaf DNA-only control (lane 6) and the no-template (water) control (lane 7). $\mathrm{M}=100$-bp ladder. The $67-\mathrm{bp} P$. effusa DNA product is detectable (at arrow on the left) in the $2 \%$ agarose gel, stained with GelRed (Huang et al. 2010).

Table 1. Summary of results from three field plot experiments to detect DNA from Peronospora effusa by polymerase chain reaction (PCR) in spinach leaves prior to symptom development ${ }^{\mathrm{a}}$

\begin{tabular}{|c|c|c|c|c|c|c|}
\hline Experiments $^{b}$ & Week 3 & Week 4 & Week 5 & Week 6 & Week 7 & Week 8 \\
\hline \multicolumn{7}{|l|}{ Field plot 1} \\
\hline Total samples examined $(n)$ & ND & 48 & 48 & 48 & 48 & 48 \\
\hline PCR-positive leaf samples $(n)$ & ND & 39 & 38 & 41 & 28 & 37 \\
\hline Samples positive $(\%)$ & ND & 81 & 79 & 85 & 58 & 77 \\
\hline Confidence interval, upper & $\ldots$ & 91 & 90 & 94 & 72 & 87 \\
\hline Confidence interval, lower & $\ldots$ & 67 & 65 & 72 & 43 & 63 \\
\hline Disease symptoms & No & No & No & Yes & Yes & Yes \\
\hline \multicolumn{7}{|l|}{ Field plot 2} \\
\hline Total samples examined $(n)$ & ND & 38 & 48 & 48 & ND & 48 \\
\hline PCR-positive leaf samples $(n)$ & ND & 3 & 16 & 40 & ND & 48 \\
\hline Samples positive $(\%)$ & ND & 8 & 31 & 83 & ND & 100 \\
\hline Confidence interval, upper & & $\ldots$ & 48 & 93 & $\ldots$ & 100 \\
\hline Confidence interval, lower & & $\ldots$ & 20 & 70 & $\ldots$ & 93 \\
\hline Disease symptoms & No & No & Yes & Yes & Yes & Yes \\
\hline \multicolumn{7}{|l|}{ Field plot 3} \\
\hline Total samples examined $(n)$ & ND & 48 & 48 & 48 & 48 & 48 \\
\hline PCR-positive leaf samples $(n)$ & ND & 15 & 16 & 45 & 46 & 48 \\
\hline Samples positive $(\%)$ & ND & 29 & 33 & 94 & 96 & 100 \\
\hline Confidence interval, upper & $\ldots$ & 46 & 48 & 99 & 99 & 100 \\
\hline Confidence interval, lower & $\ldots$ & 19 & 20 & 83 & 86 & 93 \\
\hline Disease symptoms & No & No & Yes & Yes & Yes & Yes \\
\hline
\end{tabular}

a The first leaf samples were collected 4 weeks after the planting of spinach cultivar Viroflay. ND $=$ not determined.

${ }^{\mathrm{b}}$ Not all 48 samples were processed, as in week 4 of experiment 2, because DNA was lost in the extraction. Confidence intervals were calculated based on the Clopper-Pearson exact method described by Madden et al. (2007). 
make decisions on whether or not to apply fungicides. This provides one more tool for monitoring $P$. effusa, as part of an integrated pest management that employs more than one monitoring approach. Commonly used fungicides for downy mildew and related oomycete diseases such as mandipropamid are preventative (Lebeda and Cohen 2012) but some are systemic and can have curative effects and inhibit further pathogen growth (Lebeda and Cohen 2012; Lu et al. 2011). Therefore, application of fungicides after initial DNA detection in the spinach leaves may prevent breakout of the disease within the same field or at nearby fields. Prevention of disease spread within the same field is plausible in cases where the disease is localized in a patch of the field initially, as in experiment 2 . The pathogen was detected 7 days prior to symptom development in only some leaf samples of two of the four $2-\mathrm{m}$. beds planted on the north end. Additionally, because there are continuous efforts to develop and deploy organic-friendly biopesticides for downy mildews and other diseases (Marine et al. 2016), biopesticides may also be used more effectively for disease control in organic production systems in the near future.

Previous analyses revealed that airborne $P$. effusa can be detected throughout the year, although increased detection of the pathogen was recorded during the progression of two different growing seasons (Choudhury et al. 2016). The PCR assay described herein does not provide information on whether the $P$. effusa DNA detected in the assays is derived from sporangia on the surface of spinach leaves. However, even in those events where $P$. effusa DNA is collected at plant sampling on the leaf surface, it is similarly valuable to know whether the spinach plants in the field are being challenged with $P$. effusa. Additionally, P. effusa is an obligate, host-specific pathogen that only infects spinach (Byford 1967; Klosterman et al. 2014; Thines and Choi 2016). Thus, we do not anticipate nonspecific DNA amplification in the conventional PCR from related DNA such as that of $P$. schachtii, which infects Swiss chard (Choi et al. 2015; Klosterman et al. 2014) and is grown in the same region.

The conventional PCR methodology offers advantages in comparison with other pathogen detection techniques but also may have some drawbacks. The equipment for conventional PCR is standard in most plant pathogen diagnostic laboratories, whereas qPCR equipment is less common, more expensive, and requires additional expertise to operate. The conventional PCR approach does require running the amplified DNA products on agarose gels for visualization of the positive and negative samples, and this step is not required for qPCR.

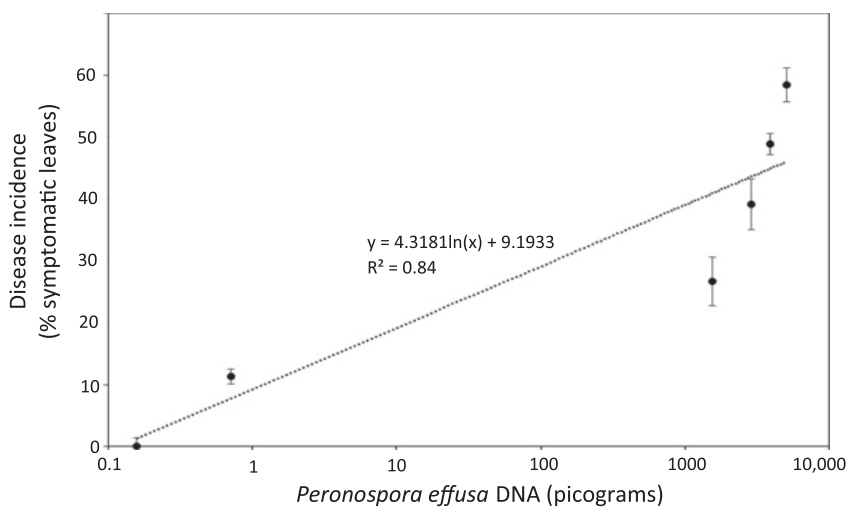

Fig. 3. Relationship between spinach downy mildew disease incidence (\%) and DNA quantities of Peronospora effusa determined by TaqMan assays using $P$. effusaspecific primer pair AS1 and PeR1 and the Pef1 probe (Klosterman et al. 2014). Each data point is the average of samples collected from each of the three fields sampled. Disease incidence was calculated from the percent downy mildew symptomatic leaves in a $0.3-\mathrm{m}^{2}$ area per sampling site for a total of approximately 48 sites collected weekly, beginning at week 4 after planting. At week 5 and week 6 , marked by 11.3 and $26.7 \%$ incidence, there were 46 and 47 samples used for quantitative polymerase chain reaction (qPCR), respectively. Samples used to calculate the standard deviation of quantification cycle values were those that yielded DNA amplification by qPCR, which included 24 samples in week 4 (0 incidence) and 48 samples in both weeks 8 (48.9\% incidence) and 9 (58.4\% incidence). Incidence refers to the percentage of leaves with downy mildew.
Detection of latent infection in plant leaves indirectly by PCR is not quantitative, unlike qPCR. The current work indicated increased sensitivity of a TaqMan assay as compared with PCR for in planta $P$. effusa DNA detection. TaqMan qPCR is 10 to 100 times more sensitive than conventional PCR (Mirmajlessi et al. 2015). The detection limit using conventional PCR was $10 \mathrm{pg}$, while the limit of detection of the TaqMan assay was $0.1 \mathrm{pg}$. Therefore, the use of qPCR may be useful to further assess the level of plant infection. However, we also noted the decreased $P$. effus $a$ DNA amplification efficiencies of the TaqMan assay in the presence of the spinach leaf extract, although this was resolved by dilution of the extract prior to the TaqMan assay. Nevertheless, internal controls as applied in other systems (Bilodeau et al. 2012; Kunjeti et al. 2016a) are useful to confirm the presence and amount of inhibition in each reaction. Previous work indicated that the P. effusa TaqMan assay, which targets the multicopy rDNA region, had a limit of detection of $10 \mathrm{fg}$ (Klosterman et al. 2014). This limit is equivalent to less than a single sporangium, based upon known sizes and predicted masses of Peronospora spp. genomes (Derevnina et al. 2015; Voglmayr and Greilhuber 1998). However, the DNA in that case (Klosterman et al. 2014) was mixed only with silicon vacuum grease from spore traps and not with spinach leaf DNA extractions.

An additional area of improvement for the detection system may include variations in sampling strategies. The absence of detection does not mean absence of latent infection and the upper confidence limit for PCR-based detection was 7.4\%. Therefore, sampling should accommodate this reality by increasing the sampling size as appropriate and even sampling earlier than demonstrated in this study. Currently, pest control advisors and food safety scouts monitor the spinach fields intensively for downy mildew and food safety concerns, at a frequency of nearly twice per week. Routine leaf sampling can be done in coordination with these efforts, and can be scaled up or down as deemed appropriate by those in the field.

Ongoing work is being directed at commercial development of a $P$. effusa DNA amplification and detection technique. Further improvements upon this current technique may include approaches that do not rely on electrophoresis and provide the grower information more quickly. Ultimately, the aim is to make technology available for use by pest control advisors and the food safety scouts that comb through the organic and conventional spinach fields for onsite testing in the field, and for even more quick assessments of downy mildewpositive samples. Recent developments in recombinase polymerase amplification and other detection methods for oomycete pathogens (Crandall et al. 2018; Miles et al. 2015) may prove useful for that purpose.

\section{Acknowledgments}

We thank M. Zischke, Chief Executive Officer, California Leafy Greens Research Program, for helpful discussions and comments on the manuscript.

\section{Literature Cited}

Atallah, Z. K., Maruthachalam, K., du Toit, L., Koike, S. T., Davis, R. M., Klosterman, S. J., Hayes, R. J., and Subbarao, K. V. 2010. Population analyses of the vascular plant pathogen Verticillium dahliae detect recombination and transcontinental gene flow. Fungal Genet. Biol. 47:416-422.

Bilodeau, G. J., Koike, S. T., Uribe, P., and Martin, F. N. 2012. Development of an assay for rapid detection and quantification of Verticillium dahliae in soil. Phytopathology 102:331-343.

Brent, K. J., and Hollomon, D. W. 2007. Fungicide Resistance in Crop Pathogens: How Can It be Managed? FRAC Monogr. No. 1, second revised edition. Fungicide Resistance Action Committee, Bristol, UK.

Byford, W. J. 1967. Host specialization of Peronospora farinosa on Beta, Spinacia and Chenopodium. Trans. Br. Mycol. Soc. 50:603-607.

Chanda, A. K., Ward, N. A., Robertson, C. L., Chen, Z. Y., and Schneider, R. W. 2014. Development of a quantitative polymerase chain reaction detection protocol for Cercospora kikuchii in soybean leaves and its use for documenting latent infection as affected by fungicide applications. Phytopathology 104: 1118-1124.

Choi, Y.-J., Hong, S.-B., and Shin, H.-D. 2007. Re-consideration of Peronospora farinosa infecting Spinacia oleracea as distinct species, Peronospora effusa. Mycol. Res. 111:381-391.

Choi, Y.-J., Klosterman, S. J., Kummer, V., Voglmayr, H., Shin, H.-D., and Thines, M. 2015. Multi-locus tree and species tree approaches toward resolving a 
complex clade of downy mildews (Straminipila, Oomycota), including pathogens of beet and spinach. Mol. Phylogenet. Evol. 86:24-34.

Choudhury, R. A., Koike, S. T., Fox, A., Anchieta, A., Subbarao, K. V., Klosterman, S. J., and McRoberts, N. 2016. Season long dynamics of spinach downy mildew determined by spore trapping and disease incidence. Phytopathology 106 : 1311-1318.

Choudhury, R. A., Koike, S. T., Fox, A. D., Anchieta, A., Subbarao, K. V., Klosterman, S. J., and McRoberts, N. 2017. Spatio-temporal patterns in the airborne dispersal of spinach downy mildew. Phytopathology 107:50-58.

Correll, J. C., Bluhm, B. H., Feng, C., Lamour, K., Du Toit, L. J., and Koike, S. T. 2011. Spinach: better management of downy mildew and white rust through genomics. Eur. J. Plant Pathol. 129:193-205.

Crandall, S. G., Rahman, A., Quesada-Ocampo, L. M., Martin, F. N., Bilodeau, G. J., and Miles, T. D. 2018. Advances in diagnostics of downy mildews: lessons learned from other oomycetes and future challenges. Plant Dis. 102:265-275.

De Boer, S. H., and Lopez, M. M. 2012. New grower-friendly methods for plant pathogen monitoring. Annu. Rev. Phytopathol. 50:197-218.

Derevnina, L., Chin-Wo-Reyes, S., Martin, F., Wood, K., Froenicke, L., Spring, O., and Michelmore, R. 2015. Genome sequence and architecture of the tobacco downy mildew pathogen Peronospora tabacina. Mol. Plant Microbe Interact. 28:1198-1215.

Eriksson, J. 1919. Zur Entwickelungsgeschichte des Spinatschimmels (Peronospora spinaciae (Grew.) Laub.). Arkiv. Bot. 15:1-25

Feng, C., Correll, J. C., Kammeijer, K. E., and Koike, S. T. 2014. Identification of new races and deviating strains of the spinach downy mildew pathogen Peronospora farinosa f. sp. spinaciae. Plant Dis. 98:145-152.

Huang, Q., Baum, L., and Fu, W.-L. 2010. Simple and practical staining of DNA with GelRed in agarose electrophoresis. Clin. Lab. 56:149-152.

Inaba, T., Takahashi, K., and Morinaka, T. 1983. Seed transmission of spinach downy mildew. Plant Dis. 67:1139-1141.

Klosterman, S. J. 2016. Spinach downy mildew-Threat, prevention and control. Prog. Crop Consult. 1:12-15.

Klosterman, S. J., Anchieta, A., McRoberts, N., Koike, S. T., Subbarao, K. V., Voglmayr, H., Choi, Y.-J., Thines, M., and Martin, F. N. 2014. Coupling spore traps and quantitative PCR assays for detection of the downy mildew pathogens of spinach (Peronospora effusa) and beet ( $P$. schachtii). Phytopathology 104:1349-1359.

Knüfer, J., Lopisso, D. T., Koopmann, B., Karlovsky, P., and von Tiedemann, A. 2016. Assessment of latent infection with Verticillium longisporum in fieldgrown oilseed rape by qPCR. Eur. J. Plant Pathol. 147:819-831.

Koike, S. T., Cahn, M., Cantwell, M., Fennimore, S. A., LeStrange, M., Natwick, E. T., Smith, R. F., and Takele, E. 2011. Spinach Production in California, Publ. 7212. University of California Division of Agriculture and Natural Resources, Monterey, CA.

Kunjeti, S. G., Anchieta, A. G., Martin, F. N., Choi, Y.-J., Thines, M., Michelmore, R. W., Koike, S. T., Tsuchida, C., Mahaffee, W. F., Subbarao, K. V., and Klosterman, S. J. 2016a. Detection and quantification of Bremia lactucae by spore trapping and quantitative PCR. Phytopathology 106:1426-1437.

Kunjeti, S. G., Anchieta, A. G., Subbarao, K. V., Koike, S. T., Anchieta, A., and Klosterman, S. J. 2016b. Plasmolysis and vital staining detect viable oospores of Peronospora effusa in multiple spinach seed lots. Plant Dis. 100:59-65.
Lebeda, A., and Cohen, Y. 2012. Fungicide resistance in Pseudoperonospora cubensis, the causal pathogen of cucurbit downy mildew. Pages 44-63 in: Fungicide Resistance in Crop Protection: Risk and Management. T. S. Thind, ed. CAB International, Wallingford, UK.

Lu, X. H., Hausbeck, M. K., Liu, X. L., and Hao, J. J. 2011. Wild type sensitivity and mutation analysis for resistance risk to fluopicolide in Phytophthora capsici. Plant Dis. 95:1535-1541.

Madden, L. C., Hughes, G., and van den Bosch, F. 2007. The Study of Plant Disease Epidemics. American Phytopathological Society, St. Paul, MN.

Mahlein, A.-K., Oerke, E.-C., Steiner, U., and Dehne, H.-W. 2012. Recent advances in sensing plant diseases for precision crop protection. Eur. J. Plant Pathol. 133:197-209.

Marine, S. C., Newark, M. J., Korir, R. C., and Everts, K. L. 2016. Evaluation of rotational biopesticide programs for disease management in organic cucurbit production. Plant Dis. 100:2226-2233.

Miles, T. D., Martin, F. N., and Coffey, M. D. 2015. Development of rapid isothermal amplification assays for detection of Phytophthora spp. in plant tissue. Phytopathology 105:265-278.

Mirmajlessi, S. M., Destefanis, M., Gottsberger, R. A., Mänd, M., and Loit, E. 2015. PCR-based specific techniques used for detecting the most important pathogens on strawberry: a systematic review. Syst. Rev. 4:9.

NASS. 2015. Agricultural Statistics 2015. National Agricultural Statistics Service. United States Department of Agriculture. U.S. Government Printing Office. Washington D.C

Nutter, F., van Rij, N., Eggenberger, S. K., and Holah, N. 2010. Spatial and temporal dynamics of plant pathogens. Pages 27-50 in: Precision Crop Protection-The Challenge and Use of Heterogeneity. E. C. Oerke, R. Gerhards, G. Menz, and R. A. Sikora, eds. Springer, Dordrecht, The Netherlands.

Ojiambo, P. S., Gent, D. S., Quesada-Ocampo, L. M., Hausbeck, M. K., and Holmes, G. J. 2015. Epidemiology and population biology of Pseudoperonospora cubensis: A model system for management of downy mildews. Annu. Rev. Phytopathol. 53:223-246.

Short, D. P. G., Gurung, S., Koike, S. T., Klosterman, S. J., and Subbarao, K. V. 2015. Frequency of Verticillium species in commercial spinach fields and transmission of $V$. dahliae from spinach to subsequent lettuce crops. Phytopathology 105:80-90.

Si Ammour, M., Bilodeau, G. J., Tremblay, D. M., Van der Heyden, H., Yaseen, T., Varvaro, L., Carisse, O. 2017. Development of real-time isothermal amplification assays for on-site detection of Phytophthora infestans in potato leaves. Plant Dis. 101:1269-1277.

Subbarao, C. S., Anchieta, A., Subbarao, K. V., and Klosterman, S. J. 2015 Molecular detection of Peronospora effusa during the latent period. (Abstr.). Phytopathology 105:S4.133.

Thines, M., and Choi, Y.-J. 2016. Evolution, diversity, and taxonomy of the Peronosporaceae, with focus on the genus Peronospora. Phytopathology 106 6-18.

Voglmayr, H., and Greilhuber, J. 1998. Genome size determination in Peronosporales wilt of lettuce (Oomycota) by Feulgen image analysis. Fungal Genet. Biol. 25:181-195.

Wu, B. M., and Subbarao, K. V. 2014. A model for multiseasonal spread of Verticillium wilt of lettuce. Phytopathology 104:908-917. 